\title{
A four-phase framework for Lean implementation in small and medium enterprises
}

Nguyen Dat Minh, Ph.D., Faculty of Industrial and Energy Management, Electric Power University, Hanoi, Vietnam, ORCID: 0000-0002-2267-4917.

Duong Trung Kien, Ph.D., Faculty of Industrial and Energy Management, Electric Power University, Hanoi, Vietnam, ID ORCID: 0000-0002-8591-2775.

\section{Introduction}

Lean term was firstly known in 1990 by Womack and Jones in the book "The Machine That Changed The World" when they were talking about the success of Toyota with the Toyota Production System (TPS) which is developed in the 1950s (Pascal, 2015; J. P. Womack, Jones, \& Roos, 1990). The most significant theory of Lean is the non-valueadded perspective via eliminating wastes, operational enhancement, and continuous improvement (Dey, Malesios, De, Chowdhury, \& Abdelaziz, 2019; Ohno, 1988; Saini \& Singh, 2020). Today, Lean is accepted and well-known all over the world as one of the most efficient methods in performance management regarding competitive viewpoints of production cost, production time and punctual delivery, set up, customer service, and after-sales service (Phan Chí Anh, 2015). By continuously applying the tools and principles of Lean, the enterprise can reach better results in production quality and services, improve productivity, reduce production time and respond quickly to customer's requirements. Applying Lean also helps up to double worker productivity, 
reduce inventories and error rates to customers by $90 \%$ and $50 \%$ respectively (J. Womack \& Jones, 2003).

In developing countries, Lean has been known and applied in both theoretical and practical business form early $21^{\text {st }}$ century. Some enterprises have achieved initial success while most have not achieved the desired results. Only less than $10 \%$ of SMEs are able to successfully access and apply Lean after one year (Nguyen Dang Minh., Nguyen Dang Toan., Nguyen Thi Linh Chi., \& Hoan, 2014). The application of Lean does not mean just putting such tools or techniques into the production system but enterprises need to identify which techniques are suitable for their production characteristics and resources in each period (Wilson, 2010). If the enterprise cannot do that to develop an implementation strategy, it will not achieve the expected success. Therefore, the objective of this paper is to provide and verifya step by step strategy fromlow-to-high level of Lean application with appropriate tools and techniques to achieve the goals in each specific phase.

\section{Literature review}

\subsection{Lean manufacturing}

Lean manufacturing or Lean isa combination of principles, tools, and techniques designed to deal with the root problems of ineffective activities in manufacturing. It isa systematic approach to eliminate all types of squanderings in the whole of the production chain in order to maximize the customers' satisfaction (J. P. Womack et al., 1990). The aim of Lean is to optimize the values of productivity, quality, cost, and ability to meet customer's requirements (Delivery) while still ensuring the safety conditions of production (Dey, Malesios, De, Chowdhury, \& Abdelaziz, 2020). As to meet these goals, Lean tries to get rid of three main sources leading to damages from the production management system: waste, volatility, and inflexibility (Drew, McCallum, \& Roggenhofer, 2004). Tools of Lean method connect together to acquire the goals of productivity, quality, cost, and delivery on time.

The foundation of the Lean house includes 5Ss system, Visual management (VM), Waste/Muda elimination, Total productive maintenance (TPM), Standardized work (SW) and Continuous improvement (Kaizen). These platforms of tools and techniques playa role in creating the stability of production systems and build up the Lean culture in the entreprise (Liker, 2006; Ohno, 1988; J. Womack \& Jones, 2003). 
The first pillar of the Lean house is Just in time (JIT). JIT means producing the right item at the right time in the right quantity, anything else is wasted, it means JIT just only producing what is necessary at that time witha necessary quantity (Pascal, 2015). Therefore, all of the activities providing more or earlier than planned are considered as waste (J. Womack \& Jones, 2003). Performing JIT in manufacturing is such an important activity to obtain the inventory reduction objection and eliminate overproduction (P. C. Achanga, 2007). The main principles of JIT is do not supply anything unless the customer has ordered it; level demand so that work may proceed smoothly throughout the plant; link all processes to customer demand through simple visual tools; maximize the flexibility of people and machinery. There are several tools are produced including Kanban, cell layout, takt time, leveling production, Value stream mapping (VSM), one-piece flow, SMED, etc... that illustrated in Figure.1 (Pascal, 2007; J. Womack \& Jones, 2003).

The second pillar of the Lean house is Jidoka. The Japanese word Ji-do-ka comprises three Chinese characters. The first "Ji" refers to the worker himself, if he feels "something is wrong" he must stop the production line. "Do" refers to motion or work, and "ka" refers to the suffix or action. Therefore, taken together Jidoka has been defined by Toyota as "Automation witha human mind" and intelligent production and taking quick countermeasures (Ohno, 1988; Pascal, 2007). In this way, automation prevents low-quality products from being sent to the next steps and does not create uncommon mistakes (Pascal, 2015). The goal of Jidoka is to prevent the risk of malfunction in production or to recognize the problems before it occurs. Jidoka also helps to identify errors, to prevent and control mistakes (Liker, 2004). Implementing Jidoka ensures standard quality and also preventing faults of machines, equipment and reducing the humanrelated activities in the production process. Some tools performing Jidoka are error prevention system (Poka-Joke) and Work control system, production introductions (Andon).

\subsection{Lean application measurement}

The performance measurement in manufacturing definesa set of metrics for manufacturing operations management. The metrics are classified into the subtopics of economics, labor, human rights, social, product responsibility, environment, and technology (Adlin, Nylund, Lanz, Lehtonen, \& Juuti, 2020). Performance measurement is one of the tools that currently had been chosen by many industry analysts, organizations, and enterprises (Smith, 2007). Measuring 
the performance of any operation needs index intervention especially in an industry which performance metrics exist.

The different research papers on Lean success indicators and their use to justify the implementation ofa Lean approach can be classified into Lean indicators, Leanness measurement, and decision aid systems, and validation of future implementations (Cortes, Daaboul, Le Duigou, \& Eynard, 2016). The purpose of any enterprise in manufacturing is to provide the highest quality at the lowest cost in the shortest time. Therefore, in the case of Lean application for improving manufacturing systems performance is also to achieve these above targets (Pascal, 2007). Clear determination of criteria expresses that businesses have been implementing successfully the Lean method into the production process, which helps the researcher to have an exact evaluation for the process and performing results of businesses in research. Pascal (2007) showed that the results of Lean are explained via four main criteria: (1) Productivity increase; (2) Quality improvement; (3) Cost reduction; (4) Delivery on time. These criteria are considered as the most important outcomes to determine that the applying of Lean in businesses is fruitful (J. Womack \& Jones, 2003). Asa basis for evaluating the success of Lean application, the economic index manifesting but not limit the Lean success measurement are developed by the authors as table 1 .

Table 1. The manifestation of Lean success measurement

\begin{tabular}{|c|c|c|c|}
\hline No & Index & Sub-index & Manifestation of Success \\
\hline \multirow{2}{*}{1} & \multirow{2}{*}{$\begin{array}{l}\text { Produc- } \\
\text { tivity }\end{array}$} & Production volume, Revenue & $\begin{array}{l}\text { Increase and maintain without or small } \\
\text { investment }\end{array}$ \\
\hline & & Manpower, material, machine & $\begin{array}{l}\text { Reduce while keep production capac- } \\
\text { ity and sustainable maintain }\end{array}$ \\
\hline \multirow[t]{2}{*}{2} & \multirow{2}{*}{ Quality } & $\begin{array}{l}\text { Defective ratio, ratio of claims from } \\
\text { customers }\end{array}$ & Reduce and maintain \\
\hline & & Ratio of good products passed directly & Keep stable or increase and maintain \\
\hline \multirow{3}{*}{3} & \multirow{3}{*}{ Cost } & Manpower cost & $\begin{array}{l}\text { Reduce manpower while still keep the } \\
\text { production plan and capacity }\end{array}$ \\
\hline & & Material cost & $\begin{array}{l}\text { Reduce material cost while keep the } \\
\text { product quality }\end{array}$ \\
\hline & & $\begin{array}{l}\text { Operational cost, Repair cost, Mainte- } \\
\text { nance cost, Energy-water cost }\end{array}$ & $\begin{array}{l}\text { Reduce and maintain while no more } \\
\text { investment and keep production activi- } \\
\text { ties continuously }\end{array}$ \\
\hline
\end{tabular}




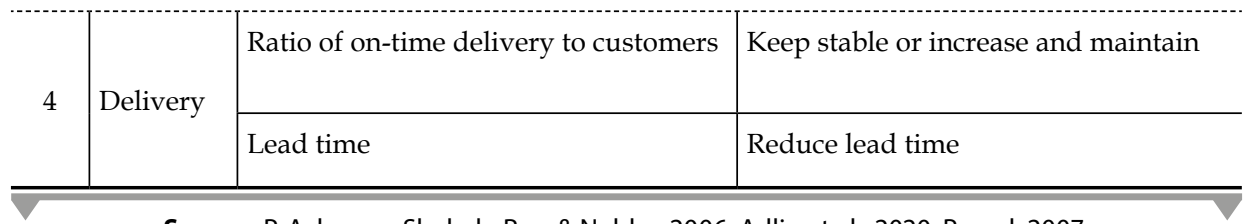

Source: P. Achanga, Shehab, Roy, \& Nelder, 2006; Adlin et al., 2020; Pascal, 2007;

J. Womack \& Jones, 2003

\section{Research methodology}

\subsection{Framework for Lean application roadmap in SMEs}

Based on the theory about the tools and techniques of Lean and the result of Lean application from six case companies combined with features of SMEs, the framework of applying successfully Lean is proposed as shown in Figure 2 including 4 phases (make the Stabilize production, make the Standardize production, make the Smoothing production, and make the Slim, production). In the condition of resources limitation, SMEs do not have enough capacities to implement synchronously at the enterprise-wide scale but should choose to apply partially, use simple and cost-free techniques. With outdated technology and equipment, there is no other way for businesses to build competitive advantage is to keep continuous improvement. Puttinga new production management method like Lean into the business will createa "change-resisted" response from workers. Therefore, the gradual introduction is the only way to help the workers accept the change more easily. Figure 2 depicts the orientation of applying Lean step by step by the conditions of SMEs.

Phase 1. Stabilize the production system. Businesses beginning Lean transition should start with Lean's simple, easy-to-implement tools and techniques to eliminate waste and form continuous improvement ideas. Implementing 5S and VM are ways to train habits and perseverance for all workers and managers to builda scientific, neat, and tidy workplace. This isa simple technique, low cost but bring high efficiency. Besides, businesses also need to ensure that machinery, production lines are not damaged, do not cause errors by TPM implementation. TPM is combined with 5Ss to carry out maintenance of machines and equipment at each position, helping the system is always ready to operate.

Phase 2. Standardize the production system. The second phase in the Lean applying process is the standardization. After members are familiar with ideas 
about waste, 5Ss, and innovative thinking, providing tools to build up standards is inevitable. Standardizing the system helps businesses control, maintain and promote the results of continuous improvement. Standards necessarily are ina clear, specific state for workers could be aware of that their work is normal or abnormal. It should also be noted that standards area great tool in the workplace, but it is constantly changing due to workers encouraged to find better ways to work.

Phase 3. Smooth the production system. The third phase of the Lean applying strategy is to smooth production. Smoothing production isa process of balancing among relevant parts in the enterprise. During this period, the business begins to put the system stabilization tools such as Leveling, Takt time, reducing batch sizes, and setting continuous flows or SMED. Implementinga smooth production system helps businesses shorten production time, eliminate problems of stopping chains and waiting. Successful implementation of smoothing means that the business is well versed in the basic techniques of Lean and forms the Lean culture via sharing and high consensus.

Phase 4. Slim the production system. Finally, after establishing the standards and operating continuously and smoothly, the enterprise needs to streamline the system. System streamlining is considered asa higher level of Lean implementation by improvement and waste elimination. Lean's tools should be applied at this stage such as settinga pull system (Kanban), Cell layout, development of intelligent automation systems such as Andon. Besides using techniques to streamline the internal production system, businesses should start thinking about balancing the system outside the business as well. An important condition for the profound implementation of JIT is to seek and developa good, stable, and highly committed supplier system for raw materials for production.

This investigation is also looking out the contribution of Lean tools application in SMEs for enhancing firm performance. Through the case study, the hypothesis is "Applying the right tools at the right phase and right condition will lead to Lean success" (improve productivity, enhance quality, reduce cost, and ontime delivery). In other words, the framework of this paper will ensure the SME manufacturers for the embracement of Lean in their production lines for attaining priorities. (Dave \& Sohani, 2019; Rahman, Laosirihongthong, \& Sohal, 2010; Ramesh \& Ravi, 2017; Sahoo, Singh, Shankar, \& Tiwari, 2008). In the next sections, the authors present the confirmation of implementing Lean roadmap as illutrated in figure 1 and confirm the impact of Lean tools selected to the successful implementation. 


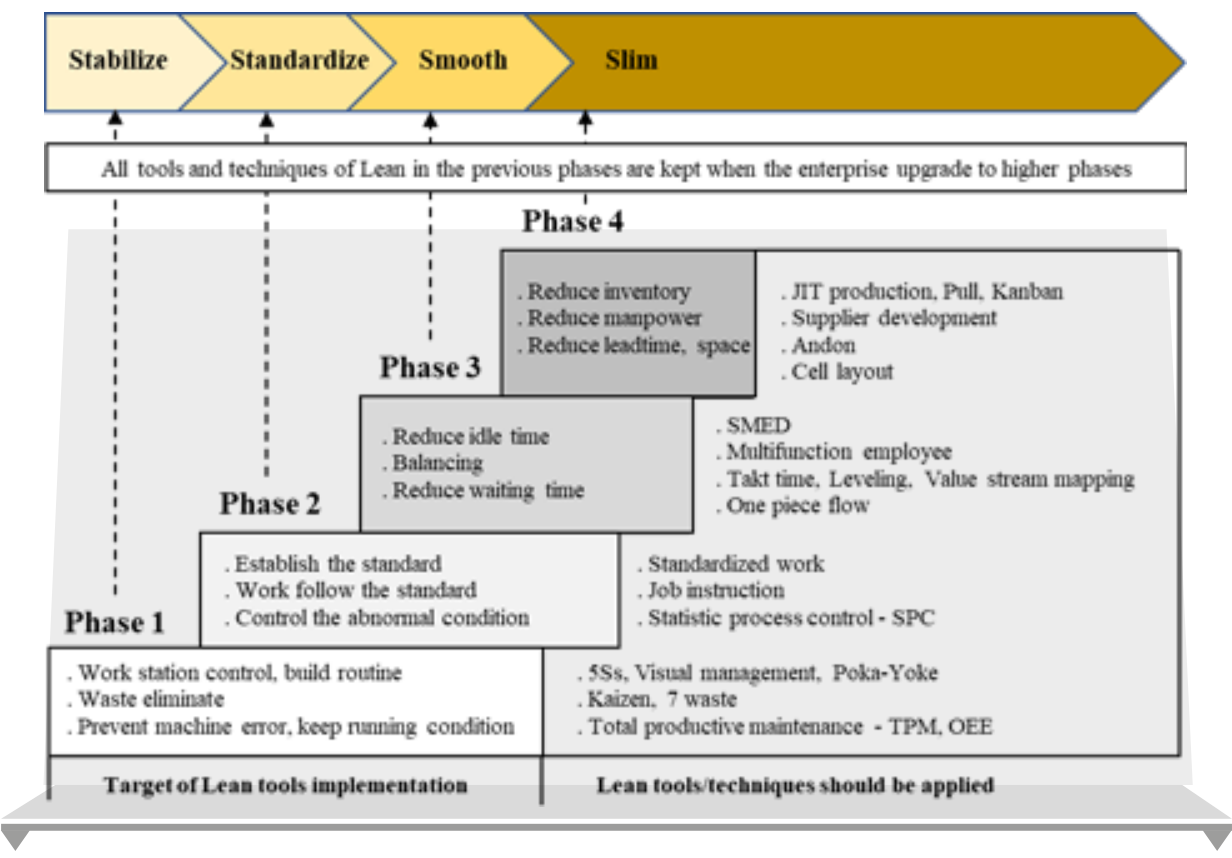

Figure 1. The framework of applying successfully Lean

Source: own study

\subsection{Case study selection}

The research was based on studies from the case of SMEs in Vietnam. The case company is considered to have participate in the research by ensuring that it has applied Lean for more than three years, achieved results on four main economic criteria of Lean include PQCD and these criteria have to be recorded for one year to get the database, and the case company is deploying Lean projects when the authors conduct the research (Pascal, 2007; J. Womack \& Jones, 2003). There are no other management systems were implemented for the production system in all case companies during this research was conducted.

In total, six SMEs in the mechanical industry located in Vietnam are identified through Vietnam Association for Supporting Industry - VASI. From the chosen companies, the production managers were contacted to 
participate in the case study research including (1) LGR Company, (2) HY Company (3) BBS Company, (4) Idmea Company, (5) TDo Company, and (6) HHa Company. Because of confidentially, the names of the companies cannot be disclosed, and therefore, several codes were subsequently developed as above.

SMEs were chosen because of the large number of total businesses and reflection on Vietnamese manufacturing enterprises. In addition, SMEs companies were chosen for this study because of the important role in Vietnam's economy and the failure deployment before. Finally, the authors selected case companies from the mechanical industry because of the very important role of this sector in Vietnam's economy, this isa priority sector in the strategy of Vietnam supporting industry development to 2030. All six case companies come from the private sector possessing typical features and represent multiple enterprises in the sector.

\subsection{Data collection and analysis}

This paper uses qualitative through case study method to collect and analyze the data. Qualitative method provides the overall view and profound understanding ofa phenomenon (Perry, 1998; Yin, 2013). Besides, the qualitative research is quite good at helping researchers acknowledge thoughtfully and respond to the questions "why" and "how" about the implementation of Lean in the production system (Easterby-Smith, Thorpe, \& Jackson, 2012; Parkhe, 1993).

Thanks to typical situations at the SMEs applying Lean, the authors also indicated the characteristics which can apply tools and principles of Lean to get successful so that proposinga suitable way for implementing Lean in Vietnamese SMEs.

The data collected by three main sources including:

1. Documents, secondary data were collected and analyzed via results of the reports about the production improvement, quality assurance, cost reduction, and other activities related to Lean implementation of the case company.

Targeted participants individual interview via the semi-structured interviews questionnaire are the ones who has experience in years and directly take part in the Lean implementation plan. The interview occurred for less than $30 \mathrm{~min}$ and repeatedly during the Lean project has been implemented in each case. The interview questionnaire focused on the following question:

- what is the general process to conducta Lean project in your company?

- how long does the time-frame fora general project? 
- what is the priority of lean tools do you use to solve the problems of production lines?

- how do you solve the problems and barriers faced during the project?

- what are the criteria to assess the success of the project?

Participation observing through joining Lean projects in case company to get more data and compared to interview results on Lean project implementation.

After receiving the interview and observe results, the authors recorded and took notes on all the related documents including Lean outcomes, the impact of SMEs features on the successful, Lean tools applied, and the impact of Lean tools selected to the successful implementation in the case companies.

\section{Research results}

\subsection{Lean application results}

\subsubsection{Frequency of implementation of Lean tools}

The results frequency of Lean tools implementation within case company shown in figure 2 indicated the leading tools are waste elimination (Muda) and Kaizen with 100 percent of six cases applied during the time. The second rank of Lean tools implemented are 5Ss, Visual management, Standardized work, and Poka-yoke (Mistake-Proofing) with 67 percent. On the bottom of the list are VSM, Kanban, and SPC with 17 percent, while all six companies did not apply TPM and Andon into the production lines. Cell layout, SMED, Leveling production, and Fix stop position rule are deployed in two of six companies at an average level with 33 percent.

Most of the Lean tools are implemented in the LGR company after 12 years while Idmea deployed 10 per 17 tools of Lean from 2015 to 2020 . HY company seems focused on the productivity improvement at the first applied with SMED, Kanban, OEE, they did not apply some basic tools of Lean (11 per 17 tools of Lean did not deploy after years include 5Ss, Visual management, Poka-Yoke). Hha company are also did not get success from Lean, the company focused on planning improvement when applied Leveling production and one-piece-flow. They did not apply any basic tools of Lean as 5Ss, Visualize, VSM, Poka-yoke. 


\begin{tabular}{|c|c|c|c|c|c|c|c|}
\hline \multirow{2}{*}{ Lean Tool applied } & \multicolumn{6}{|c|}{ Case company } & \multirow{2}{*}{ Frequency $(\%)$} \\
\hline & LGR & HY & BBS & Idmea & TDo & Hha & \\
\hline Wastes eliminate & $\sqrt{ }$ & $\sqrt{ }$ & $\sqrt{ }$ & $\sqrt{ }$ & $\sqrt{ }$ & $\sqrt{ }$ & $100 \%$ \\
\hline $5 \mathrm{~S}$ & $\sqrt{ }$ & & $\sqrt{ }$ & $\sqrt{ }$ & $\sqrt{ }$ & & $67 \%$ \\
\hline Visualize management & $\sqrt{ }$ & & $\sqrt{ }$ & $\sqrt{ }$ & $\sqrt{ }$ & & $67 \%$ \\
\hline Kaizen & $\sqrt{ }$ & $\sqrt{ }$ & $\sqrt{ }$ & $\sqrt{ }$ & $\sqrt{ }$ & $\sqrt{ }$ & $100 \%$ \\
\hline Standardized work & $\sqrt{ }$ & $\sqrt{ }$ & $\sqrt{ }$ & & $\sqrt{ }$ & & $67 \%$ \\
\hline TPM & & & & & & & $0 \%$ \\
\hline VSM & $\sqrt{ }$ & & & & & & $17 \%$ \\
\hline Cell Layout & & & & $\sqrt{ }$ & $\sqrt{ }$ & & $33 \%$ \\
\hline SMED & $\sqrt{ }$ & $\sqrt{ }$ & & & & & $33 \%$ \\
\hline Kanban & & $\sqrt{ }$ & & & & & $17 \%$ \\
\hline One Piece Flow & $\sqrt{ }$ & & & $\sqrt{ }$ & & $\sqrt{ }$ & $50 \%$ \\
\hline Heijunka/Leveling & & & $\sqrt{ }$ & & & $\sqrt{ }$ & $33 \%$ \\
\hline Poka-Yoke & $\sqrt{ }$ & & $\sqrt{ }$ & $\sqrt{ }$ & $\sqrt{ }$ & & $67 \%$ \\
\hline Adon & & & & & & & $0 \%$ \\
\hline Fix Stop Position & $\sqrt{ }$ & & & $\sqrt{ }$ & & & 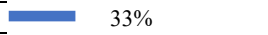 \\
\hline OEE & $\sqrt{ }$ & $\sqrt{ }$ & & $\sqrt{ }$ & & & $50 \%$ \\
\hline SPC & & & & $\sqrt{ }$ & & & $17 \%$ \\
\hline
\end{tabular}

Figure 2. Percentage of case companies that implemented Lean tools

Source: own study

\subsubsection{Performance outcome}

The LGR company after 11-year business in Vietnam increase productivity up to $280 \%$ from 16,000 products per year as designed to 44,800 products per year in 2020 without any large investment. Production cost reduced more than 15\% in the period 2013-2015 (Production cost of product type-V model was reduced from 20,167 USD/product to 17,169 USD/product). On average, the number of faults per product decreased from 0.14 faults in 2011 to 0.065 faults in 2020. The outcomes of productivity, quality, and cost are always maintained continuously by the company when applying Lean until now.

BBS company after 7-year of Lean application, reduced the die-change time more than $60 \%$ (Stamping workshop), areas of factory cut back to $65.7 \%$ (Hub workshop), and increased capacity to $32 \%$ (welding workshop), inventory reduction to $90 \%$ (Welding components warehouse No.1). In some states, the probability of defective products is eliminated up to $96 \%$ and that of failure is cut back by $10 \%$ per year. In 2019, BBS continues to seta goal of production cost saving more than 5\% and increase on-time delivery from $96 \%$ to $99 \%$.

Idmea increases productivity more than $20 \%$, probability of defective products for 2 production lines occurred frequently have been reduced more than $96 \%$ 
in the 3-year period 2015-2018. Inventory of work-in-process decreased 68\%, reduce $78 \%$ of Leadtime, which contributed vastly to reduce production cost. The strategy of Idmea's top management is to "keep investing technology, develop the human resource and step by step apply Lean methods to improve production capacity in the factory more than $10 \%$ each year".

In the case of TDo, applying Lean after 5 years helps to improve the productivity, the revenue of the company increased continuously by approximately $47 \%$ per year, lead time decreased 32\% while investment of infrastructure and labor is insignificant. In 2018, the rate of defective products of the enterprise supplied to customers reduced from $45 \mathrm{ppm}$ (part per million) to less than $10 \mathrm{ppm}$. In addition, the ratio of errors in all products producing domestic goods is reduced to less than $2 \%$. "There is no customers' complain about the product's quality, production cost in some lines providing for FDI clients is reduced more than 30\%. We keep maintained production control and processes Kaizen to ensure the quality and declined defective products rate to $0 \%$ in 2022 .

In the case of HY company, after one year deployed Lean (from 2013 to 2014) and start with Kaizen, Muda helps to improve the reuse ratio of the raw material of Inox No.304 from $17 \%$ to $42 \%$, delivery time from warehouse to cutting line reduced from 138 seconds to 46 seconds, and lot size was also reduced from 160 pieces per lot to 10 pieces per lot. However, the results of productivity, cost, delivery are not maintained over years.

The last case that participated in the research is HHa company. HHa Company after 3 years of applying Lean did not obtain expected outcomes in general and some results are also not kept. The authors summarize the applying Lean results in the case companies from the four main economic criteria mentioned above. The result of Lean application as shown in table 2 .

Table 2. The summarization of the applying Lean results in case companies

\begin{tabular}{c|l|l|l|l}
\hline & \multicolumn{1}{|c|}{ Productivity } & \multicolumn{1}{c|}{ Quality } & \multicolumn{1}{c}{ Cost } & \multicolumn{1}{c}{ Delivery } \\
\hline LGR & Increase 280 per cent & $\begin{array}{l}\text { Reduce 215 per cent } \\
\text { of faults per product }\end{array}$ & $\begin{array}{l}\text { Reduce 14 per cent } \\
\text { of production cost }\end{array}$ & $\begin{array}{l}\text { Zero delay deliv- } \\
\text { ery to all dealers }\end{array}$ \\
\hline HY & $\begin{array}{l}\text { Increase raw material } \\
\text { reuse from 17 to 42 } \\
\text { per cent (2013-2014) }\end{array}$ & $\begin{array}{l}\text { Did not have data to } \\
\text { record }\end{array}$ & $\begin{array}{l}\text { Reduce lot size } \\
\text { from 160 to 10 } \\
\text { pieces per lot }\end{array}$ & $\begin{array}{l}\text { Delivery time } \\
\text { reduced from 138 } \\
\text { to 46 seconds }\end{array}$ \\
\hline
\end{tabular}




\begin{tabular}{c|l|l|l|l}
\hline BBS & $\begin{array}{l}\text { Increase capacity 32 } \\
\text { per cent }\end{array}$ & $\begin{array}{l}\text { Cut back 10 per cent } \\
\text { of failure }\end{array}$ & $\begin{array}{l}\text { Save 67.5 percent } \\
\text { layout; reduce 90 } \\
\text { percent of stock }\end{array}$ & $\begin{array}{l}\text { On-time delivery } \\
\text { up to 99 per cent }\end{array}$ \\
\hline Idmea & $\begin{array}{l}\text { Improve productivity } \\
20 \text { per cent }\end{array}$ & $\begin{array}{l}\text { Reduce 96 per cent } \\
\text { of defectives }\end{array}$ & $\begin{array}{l}\text { Reduce 68 per cent } \\
\text { of work in process }\end{array}$ & $\begin{array}{l}\text { Reduce 78 per } \\
\text { cent of Leadtime }\end{array}$ \\
\hline Tdo & $\begin{array}{l}\text { Increase of revenue } 47 \\
\text { per cent per year }\end{array}$ & $\begin{array}{l}\text { Defective ratio from } \\
45 \text { ppm to } 10 \text { ppm }\end{array}$ & $\begin{array}{l}\text { Cost reduced 30 per } \\
\text { cent in some lines }\end{array}$ & $\begin{array}{l}\text { Reduce 32 per } \\
\text { cent of Leadtime }\end{array}$ \\
\hline HHa & $\begin{array}{l}\text { Did not achieve any } \\
\text { significant result of } \\
\text { Lean success after } 3 \\
\text { years. }\end{array}$ & & & \\
\hline
\end{tabular}

\subsection{Characteristics of SMEs and its impact on Lean application outcome}

\subsubsection{Characteristics of Vietnamese SMEs}

To takea more detail of the explanation of the results, this research results also indicated that the characteristics of the enterprise have significantly affected the Lean applying' outcome due to the affection because of the limited of Lean's apply from their lack characteristics. That explains why the foreign enterprises attain more success than Vietnam's. Six features of SMEs affecting the choice of tools, techniques of Lean, including: (1) Business size, (2) Technology level, (3) Management Capacity, (4) Quality of labor, (5) Corporate culture, and (6) Ability of Supply chain Link of the enterprise.

Firstly, regarding the size of the enterprise, in 2016 Vietnam has 391,777 $(97.7 \%)$ of 401,000 businesses that are small and medium-sized enterprises SMEs (Hương, 2016), and in 2020 the number of SMEs up to 593,629 of 610,637 businesses with 97.2\% (Vietnam Ministry of Planning and Investment, 2020). That why in Vietnam there are only less than 10\% of SMEs enterprises can achieve success when applying Lean fora year (Nguyen Dang Minh. et al., 2014). HY company is the typical one for SMEs whose resources are inadequate for establishing and following the principle systems as well as reward policies long enough. Similarly, the state businesses and SMEs in this research are independent on the systems provided by the suppliers while responding maximally to the customer's requirements. Thus, providing the large resources 
for synchronous applying Lean on an enterprise-wide scale seems less possible than prioritizing simple, non-investment-based tools and techniques and technology.

Secondly, the technology level of Vietnamese enterprises recently backward compared to other countries by 10 to 20 years, especially the state enterprises, small and medium-sized companies (An, 2015). In 2016, more than 52\% of Vietnam businesses using fogy technology when sole $10 \%$ of them is applying state-of-the-art technology into the production. Especially, in accordance with the report of the Vietnam Chamber of Commerce and Industry (2019), $60 \%$ of Vietnam enterprises using more than 6-year-old equipments and most of them came from China with $26.6 \%$, Japan, EU, and Korea (32\%) with $18 \%$ are imported before 2005 (Vietnam Chamber of Commerce and Industry VCCI, 2019). For example, in the case of HY company, they applied SMED and E-Kanban into the Honda Motorbike starter parts process but some processes of the whole system of drill and lathe machines are operated for more than 30 years, therefore, it is very difficult to synchronized conduct Kaizen ideas in the whole line. Due to this situation, enterprises cannot ask for synchronously Lean but just apply step-by-step from simple techniques that are suitable for the level of technology in reality, and after reachinga new higher level in technology, Lean's premium tools should be used at that time (Tiamaz \& Souissi, 2019).

Thirdly, the production management capacity of Vietnamese enterprises recently has certain limitations (Bui Thi Nga, 2019). Management competency of enterprise managers and leaders have not met the requirements in competitive and flexible production conditions (Hương, 2016). Lean implementation isa transformational process and needs to support organizational development alongside process improvement. Therefore, given contextual knowledge of the organization, to predict which Lean methods are most important in the situation (Pearce \& Pons, 2013). The production director of HHa said that he "always participate every Lean projects" when author conducted the interview but he did not involve in the meetings and reports during the Lean project occurs. The level of commitment for joining in the process weakly brings about the fact that decisions made in the meeting can not be proposed. Therefore, aftera year, applying Lean firstly in HHa was failed. Thus, the suitable way is that SMEs should change gradually and implementinga pilot project in some areas before applying an enterprisewide scale. That will createa Lean Culture in the workshop areas before starting the next higher steps in the Lean journey. 
Fourthly, Viet Nam's labor productivity was lowest among Northeast Asia and ASEAN countries, including Cambodia (Vietnam National University, 2018). There are only $24,1 \%$ of worker has been trained and more than $70 \%$ of them are unskilled labor (General Statistics Office of Vietnam, 2021). Low quality of human resources leads toa low chance of self-awareness and perception changing for applying Lean. Only when the workers recognize the role and personal responsibility for Lean development, the enterprise could gain total success. The result of Lean implemented in HY gave strong evidence of the mirror of the failure because of wrong Lean tools choice. If the independent tools of Lean are selected to apply first as 5S, Kaizen, Muda..., the results may differ. Therefore, building up the day by day practice and changing the mindset are the first necessary steps to the success of Lean.

Fifthly, the corporate culture of Vietnamese enterprises reflexes the culture of Vietnamese (Do, Quilty, Milner, \& Longstaff, 2007).A group of authors Duong Thi Lieu \& Nguyen Van Ha (2008) indicated the limitation of Vietnamese culture affecting the development process and integration of the company, such as (1) small business and unplanned habits, (2) limited vision and short-term thinking, (3) lack of connection, community, (4) rely on the relationship, (5) does not keep the trust (Dương Thị Liễu. \& Hà, 2008). While, Lean culture focuses on team works, sharing information, and continuous thinking innovation (Pascal, 2007; J. Womack \& Jones, 2003). Apparently, cultural characteristics in Vietnamese businesses do not fit the Lean features. Thus, to apply Lean successfully, the enterprises necessarily apply management strategy in long-term changing but step-to-step starting from basic tools and techniques.

Last but not least, Lean applying successfully means that the enterprise need to achieve JIT and establisha production system "Pull" from up-stream to down-stream. Nevertheless, the supply chain system in Vietnam has not createda stable chain from suppliers to manufacturers yet, producers need to import goods abroad costly with large quantity, high risk and unstable quality. Connection and cooperation among Vietnamese businesses are not really good (Linh \& Huong, 2020). Additionally, uncertainty ina supplying chain and the lack of linkage among partners are barriers to perform JIT successfully. Thus, in the first period of Lean journey, the Vietnam enterprises should focus on the Lean internal activities as 5Ss, waste elimination, Kaizen. It is an important notice for choosing suitable Lean strategies in the situation of Vietnam's enterprises. In this study, only the company LGR can takea succeed at the highest level thanks to the support of providers and customers systems. 
In conclusion, the results of case studies of six typical businesses show that the success of Lean application for enterprises is depended on the features of the enterprise. Besides that, level of Lean achievement for each case company are also depended on which tools of Lean are implemented ina suitable period or not. For example,a SMEs enterprise is hard to success with some high level or complicated Lean tools at the first years such as Kanban, Andon, Pull production... but also some simple single and independent tools and principles as 5S, VM, Kaizen are easier to applied and achieved first success. The general remark from this results as follows:

- it should be emphasized that in the case companies, the application of basic tools in the foundation of Lean house such as 5Ss, Muda, Kaizen, Visual management, Standardized work, VSM mostly achieved the success ina general level after several years,

- it is difficult to get success from the complicated tools of Lean such as Kanban, Leveling, One-piece-flow without its basic tools such as 5Ss, Kaizen, Visualize... The reason can be found in the fact that the above methods are dependent on each other. We cannot deploy Kanban without visualizing signal or implement Leveling within one production line only while application of 5Ss or Kaizen is possible without changing some of the essential pillars of the functioning of the company,

- applying step by step of Lean tools are the most suitable in the situation of SMEs or any enterprises that newly with Lean because of the limitation of resources such as human resource, financial resource, and time resource.

\section{Conclusion}

This paper isa good reference for SMEs to havea roadmap to successful application of Lean in the context of resources limitation. The proposed roadmap could be expanded to other sectors such as textile and garment, plastic, and woods, etc. This result is alsoa good experience for enterprises in developing countries in achieving higher and sustainable performance via Lean application. The findings of this paper are also support similar research of (P. Achanga et al., 2006; Antony, Hilton, \& Sohal, 2012; Robert Minovski, 2018; Tiamaz \& Souissi, 2019) in the conclusion that there is no essential obstacle for the mutual implementation of approaches.

Further research should developa detailed model ofa suitable Lean roadmap for each industry and another type of enterprise size. In addition, in the context of industry 4.0, next research should consider the role of technology and Artificial 
Intelligence (AI) to optimize the effectiveness of Lean tools and techniques applied.

\begin{abstract}
A four-phase framework for Lean implementation in small and medium enterprises

Although Lean has been known and applied in both theoretical and practical on around the world for many years, a deeper understanding of Lean tools, principles implementation, anda roadmap to successfully apply is needed. In the context of Small and medium enterprises (SME), it is very difficult for local enterprises to apply synchronization Lean tools, techniques, and principles because of limited resources in manpower, technology, and management capability. Through the case-based study, this paper proposed the four-phase roadmap for Lean application in SMEs. An analysis of methods froma literature review of Lean implementation was conducted in order to identify the phases of the roadmap. Then, six SMEs in Vietnam that applied Lean were chosen to collect data and analyze the applicability and how Lean tools are successful implemented in the cases to confirm the findings.
\end{abstract}

Keywords: Lean Application, Lean Manufactruing, Lean outcome, Small and medium enterprise.

JEL

Classification: D2, D24, L1, M11, M21

\title{
References
}

Achanga, P., Shehab, E., Roy, R., \& Nelder, G. (2006). Critical success factors for lean implementation within SMEs. Journal of Manufacturing Technology Management, 17(4), 460-471.

Achanga, P. C. (2007). Development of an impact assessment framework for lean manufacturing within SMEs. Cranfield University.

Adlin, N., Nylund, H., Lanz, M., Lehtonen, T., \& Juuti, T. (2020). Lean Indicators for Small Batch Size Manufacturers in High Cost Countries. Procedia Manufacturing, 51, 1371-1378.

An, T. (2015). Công nghệ Việt Nam lạc hậu 2-3 thế hệ với thế giới (Publication no. http://baodatviet.vn/khoa-hoc/cong-nghe/cong-ngheviet-nam-lac-hau-2-3-the-he-voi-the-gioi-3283451/). 
Antony, J., Hilton, R. J., \& Sohal, A. (2012).A conceptual model for the successful deployment of Lean Six Sigma. International Journal of Quality $\mathcal{E}$ Reliability Management, 29(1), 54-70.

Bui Thi Nga, N. D. H. (2019). Working Capacity of Managers in Small and Medium Enterprises:A Case Study in Bac Ninh Province of Vietnam. South Asian Research Journal of Business and Management, 1(2), 34-40.

Cortes, H., Daaboul, J., Le Duigou, J., \& Eynard, B. (2016). Strategic Lean Management: Integration of operational performance indicators for strategic lean management. IFAC-PapersOnLine, 49(12), 65-70.

Dave, Y., \& Sohani, N. (2019). Improving productivity through Lean practices in central India-based manufacturing industries. International Journal of Lean Six Sigma, 10(2), 601-621.

Dey, P. K., Malesios, C., De, D., Chowdhury, S., \& Abdelaziz, F. B. (2019). Could lean practices and process innovation enhance supply chain sustainability of small and medium-sized enterprises? Business Strategy and the Environment, 28(4), 582-598.

Dey, P. K., Malesios, C., De, D., Chowdhury, S., \& Abdelaziz, F. B. (2020) The impact of lean management practices and sustainably-oriented innovation on sustainability performance of small and medium-sized enterprises: empirical evidence from the UK. British Journal of Management, 31(1), 141-161.

Do, T., Quilty, M., Milner, A., \& Longstaff, S. (2007). Business culture issues in Vietnam: Case studies. In J. Fuming (Ed.), Working paper series (Vol. 2, pp. 1-49): The Australian National University.

Drew, J., McCallum, B., \& Roggenhofer, S. (2004). Journey to lean: making operational change stick: Springer.

Dương Thị Liễu., \& Hà, N. T. V. (2008). Hội nhập và văn hóa kinh doanh Việt Nam. Paper presented at the Hội thảo Quốc tế Việt Nam học lần thứ 3 do Viện Khoa học xã hội Việt Nam và Đại học Quốc gia Hà Nội phối hợp tổ chức, Hanoi.

Easterby-Smith, M., Thorpe, R., \& Jackson, P. R. (2012). Management research: Sage.

General Statistics Office of Vietnam. (2021). Thông báo tình hình lao động việc làm năm 2020. from www.gso.gov.vn

Hương, Đ. T. (2016). Đào tạo cán bộ quản lý trong doanh nghiệp nhỏ và vừa: Một số đánh giá đề xuất. Tạp chí Khoa học Đại học Quốc gia Hà Nội, Kinh tế và Kinh doanh, 23(1), 31-39.

Liker, J. (2004). The 14 principles of the Toyota way: an executive summary of the culture behind TPS. The Toyota Way, 14, 35-41.

Liker, J. (2006). The Toyota way fieldbook: Esensi.

Linh, P. N. M., \& Huong, N. T. T. (2020). The Supply Chain and Logistics of Vietnam in the context of international economic integration. International Business Research, 13(7), 27-44. 
Nguyen Dang Minh., Nguyen Dang Toan., Nguyen Thi Linh Chi., \& Hoan, T. T. (2014). Lean Management Application in Vietnam SMEs. Journal of Science-Vietnam National University, 1, 63-71.

Ohno, T. (1988). Toyota production system: beyond large-scale production: crc Press.

Parkhe, A. (1993). "Messy" research, methodological predispositions, and theory development in international joint ventures. Academy of Management review, 18(2), 227-268.

Pascal, D. (2007). Lean Production Simplified - 2rd edition. New York: Productivity Press Inc.

Pascal, D. (2015). Lean Production simplified:A plain-language guide to the world's most powerful production system: CRC Press.

Pearce, A., \& Pons, D. (2013). Implementing lean practices: managing the transformation risks. Journal of industrial engineering, 2013, 1-19.

Perry, C. (1998). Processes ofa case study methodology for postgraduate research in marketing. European journal of marketing, 32(9/10), 785-802.

Phan Chí Anh. (2015). Quản trị sản xuất tinh gọn: Một số kinh nghiệm quốc tế. Hà Nội: NXB Đại học Quốc Gia Hà Nội.

Rahman, S., Laosirihongthong, T., \& Sohal, A. S. (2010). Impact of lean strategy on operational performance:a study of Thai manufacturing companies. Journal of Manufacturing Technology Management, 21(7), 839852.

Ramesh, N., \& Ravi, A. (2017). Enhancing the performance of micro, small and medium sized cluster organisation through lean implementation. International Journal of Productivity and Quality Management, 21(3), 325-342. Robert Minovski, B. J., Petar Galevski,. (2018). Lean implementation and implications: experiences from Macedonia. International Journal of Lean Six Sigma, 12(1), 78-97.

Sahoo, A. K., Singh, N., Shankar, R., \& Tiwari, M. (2008). Lean philosophy: implementation ina forging company. The International Journal of Advanced Manufacturing Technology, 36(5-6), 451-462.

Saini, S., \& Singh, D. (2020). Impact of implementing lean practices on firm performance:a study of Northern India SMEs. International Journal of Lean Six Sigma, 11(6), 1019-1048.

Smith, F. O. (2007). KPIs made easy. Control Engineering, 54(1), 42-46.

Tiamaz, Y., \& Souissi, N. (2019). Lean roadmap:a step by step guide fora process manager. International Journal of Innovative Technology and Exploring Engineering, 8(9), 3171-3177.

Vietnam Chamber of Commerce and Industry - VCCI. (2019). Trình độ công nghệ doanh nghiệp Việt lạc hậu, gần $60 \%$ vẫn sử dụng giải pháp tuổi đời trên 6 năm. https://viettimes.on/.

Vietnam Ministry of Planning and Investment. (2020). 2020 Vietnamese Enterprises white book: Statistics Publishing. 
Vietnam National University. (2018). Vietnam Annual Econoic Report 2018. In O. K. Nguyen Duc Thanh. (Ed.).

Wilson, L. (2010). How to implement lean manufacturing: McGraw Hill Professional.

Womack, J., \& Jones, D. (2003). Lean Thinking, revised ed: Free Press, New York.

Womack, J. P., Jones, D. T., \& Roos, D. (1990). Machine that changed the world: Simon and Schuster.

Yin, R. (2013). Case study research: Design and methods Thousand Oaks, CA: Sage. 